\title{
An intonational grammar for Icelandic
}

\section{Nicole Dehé}

The aim of this paper is to shed new light on the tonal grammar of Icelandic and to complement the tone inventory as previously described in the literature (Árnason 1998). Specifically, types of pitch accents and edge tones and their combinations in neutral declaratives and questions, and in utterances containing narrow focus are addressed. Two pitch accent types $\left(\mathrm{H}^{*}\right.$ and $\left.\mathrm{L}^{*}\right)$ and two edge tones ( $\mathrm{H}-$ and $\left.\mathrm{L}-\right)$ are identified, for which evidence has not been found in previous research. Moreover, the paper shows for declaratives, that along with downstep, Icelandic has upstep across Intonational Phrases. Upstep applies to a series of pitch peaks. It may occur in neutral declaratives and in utterances with final narrow focus. Overall, the results of this study provide a substantial addition to our knowledge of Icelandic intonational phonology.

Keywords downstep, edge tones, focus, Icelandic, Icelandic intonational phonology, pitch accents, upstep

Nicole Dehé, Freie Universität Berlin, Institut für Englische Philologie, Habelschwerdter Allee 45, 14195 Berlin, Germany.ndehe@zedat.fu-berlin.de

\section{INTRODUCTION}

Unlike Swedish and Norwegian, Icelandic does not have lexical tones (Thráinsson 1994). More specifically, there is no equivalent to the binary tone contrast on the syllable bearing primary stress that has been observed for Swedish and Norwegian (see e.g. Gårding 1998 for Swedish, Kristoffersen 2000 for Norwegian, and Gussenhoven 2004:209-223 for a recent overview and further references). As in English, the Icelandic lexicon does not specify the shape of the pitch accent realized on a lexical item, it does, however, specify the potential locus of the pitch accent, which falls onto the stressed syllable. As a rule, word stress falls on the first syllable of a word (Einarsson 1973; Árnason 1985, 1987, 1998; Thráinsson 1994); see (1). Icelandic shares this property with a number of other languages, among them Bengali (see Hayes \& Lahiri 1991:55, and references given there) and Finnish (Iivonen 1998:315).

\section{(1) Icelandic word stress}

Stress the initial syllable of a word.

Moreover, there is 'a tendency for the third syllable to have secondary stress', illustrated in (2) (Árnason 1985:94, referring to Jóhannson 1924). This also holds 
for compounds, both if the first component is monosyllabic as in (3a) and if the first part is bisyllabic as in (3b). The typical Icelandic word rhythm is thus Swsw (with $\mathrm{S}=$ main/primary stress, $\mathrm{w}=$ weak, $\mathrm{s}=$ secondary stress). There are, however, exceptions to this rule. In certain compounds, notably if the first part of the compound is trisyllabic and the second component can occur as a separate word, two weak syllables occur between two strong ones, yielding a Swws rhythm (Árnason 1985, 1987; see (4)). However, the rule stating that lexical items are prosodically left-headed holds across the board. The examples in (2)-(4) and the stress patterns given there are taken from Árnason (1985:94).

(2) a. 'kennar,anum 'the teacher, DAT'

b. 'hamar,inn 'the hammer'

(3) a. 'ungbarn, ið 'the young child' (ung 'young'; barnið 'the child')

b. 'forðabúr 'storage room' (forða 'supplies, GEN'; búr 'pantry')

(4) 'höfðingja vald 'aristocracy' (höfðingja 'chieftain, GEN.PL'; vald 'power')

In Icelandic, pitch accents are intonational and focus-marking. The accent type realized on the stressed syllable depends on linguistic and paralinguistic context and speaker, rather than on phonological and morphological rules. In contrast to the leftheadedness of lexical items, normal sentence stress is rightmost, i.e. under normal stress, prominence falls onto the 'last main constituent of an utterance' (Árnason 1985:93, 1998; see (5a)). The rule is illustrated in (6a), where prominence falls on the head noun of the sentence-final NP. Rightmost sentence stress holds unless otherwise required by the focus structure of the sentence. Árnason (1985:93) notes that contrastive stress 'can be assigned to almost any part of the utterance'. In general, focused constituents are marked by pitch accents anywhere in the sentence (see (5b) and (6b)). However, we know from Nolan \& Jónsdottir (2001) that given information does not have to be deaccented (see section 3.3 below). In an utterance with narrow focus, we may thus find retained prominence on non-focused constituents (see section 3.2 below). Note that in (6), the word that carries main prominence is capitalized.

(5) Icelandic sentence stress

a. Under neutral focus, the rightmost constituent is the most prominent one.

b. Focused constituents are prominent.

(6) a. Siggi á rauðan HEST. (normal sentence stress)

Siggi has red horse

'Siggi has a red horse.

b. SIGGI á rauðan hest. (subject focus)

According to Árnason's (1998) pioneering work, the basic tone system of Icelandic has two bitonal pitch accents. In general, bitonal pitch accents consist of a 
starred tone $\mathrm{T}^{*}$ that is phonologically linked to the strong syllable, and an unstarred tone which precedes (LEADING TONE) or follows (TRAILING TONE) the starred tone 'at some given space in time' (Beckman \& Pierrehumbert 1986:257). In Icelandic, the most frequent pitch accent is $\mathrm{H}^{*} \mathrm{~L}$, i.e. a peak on the stressed syllable with a subsequent fall (a low trailing tone). This is illustrated in (7a), where $\mathrm{H}^{*}$ falls on the first syllable of Disa, followed by a fall on the adjacent syllable. Along with $\mathrm{H}^{*} \mathrm{~L}$ we find $\mathrm{L}^{*} \mathrm{H}$, i.e. a low extreme on the stressed syllable with a subsequent rise (a high trailing tone), illustrated in (7b). The syllables which bear the given pitch accent are capitalized.

(7) a. Parna er DÍsa komin.

$\mathrm{H}^{*} \mathrm{~L} \quad \mathrm{~L} \%$

there is Dísa arrived

'Dísa has arrived.'

b. Er DÍsa komin?

$\mathrm{L}^{*} \mathrm{H} \quad \mathrm{L} \%$

is Dísa arrived

'Has Dísa arrived?' (both examples from Árnason 1998:53)

Árnason (1998:53f.) discusses the question of whether the two pitch accents he identifies should be seen as bitonal or should rather be analysed as, for example, monotonal pitch accents with a following phrase accent. His main argument is that in Icelandic, for both $\mathrm{H}^{*} \mathrm{~L}$ and $\mathrm{L}^{*} \mathrm{H}$ it holds that the trailing tone has to immediately follow the starred tone, i.e. it occurs on the same or on the adjacent syllable. For the downward movement in an $\mathrm{H}^{*} \mathrm{~L}$ combination, Árnason observes that it is completed by the time the next vowel is reached (see his example given in (7a) above): the fall is completed on $-s a$ ). It seems therefore that the limit of the 'given space in time', as Beckman \& Pierrehumbert put it, can be defined for Icelandic as the end of the syllable immediately following the one associated with the starred tone.

Along with the two bitonal pitch accents, Árnason (1998) identifies two boundary tones for Icelandic: $\mathrm{H} \%$ and $\mathrm{L} \%$. In intonational phonology, edge tones are tones that are associated with the edges of phrasal prosodic constituents. In the relevant literature, two kinds of edge tones have been assumed: boundary tones and phrase accents (e.g. Pierrehumbert 1980, Beckman \& Pierrehumbert 1986). The domain of a complete intonational contour is the Intonational Phrase (IP). A boundary tone (T\%) is aligned with the edge of IP. Each IP is made up of one or more Intermediate Phrases (ip), which are terminated by phrase accents (T-). In Pierrehumbert (1980), the assumption of the phrase accent $\mathrm{T}$ - was mainly motivated by the observation that two tonal targets can be identified after the nuclear pitch accent, i.e. that there is a tone after the last pitch accent but before the phrase boundary. In Beckman \& Pierrehumbert (1986:256) the phrase accent in English is defined as 'a tone that fills the space after the last pitch accent in a phrase'. It 'controls the f0 between the last pitch accent of 
the intermediate phrase and the beginning of the next intermediate phrase - or the end of the utterance' (Pierrehumbert \& Hirschberg 1990:277). Unlike the unstarred tone in a bitonal pitch accent, the position of the phrase accent is therefore defined relative to the phrase edge. Since phrase accents terminate the Intermediate Phrase while boundary tones terminate the Intonational Phrase, Beckman \& Pierrehumbert (1986) argue that T- should be able to occur not only in combination with T\%, but also medially, at the edge of an Intermediate Phrase followed by another Intermediate Phrase in the same Intonational Phrase.

In more recent work, the phrase accent has been associated with a stressed syllable following the nucleus. Evidence for the existence of the phrase accent is given in Grice, Ladd \& Arvaniti (2000) across a range of languages. They argue that phrase accents are edge tones primarily, but that they may have 'an additional or alternative tendency to co-occur with a stressed syllable or some other designated tone-bearing unit' (Grice et al. 2000:144). Grice \& Baumann (2002:280, 295) maintain for German specifically that the anchor point of a phrase accent is often a post-nuclear, lexically stressed syllable. From this point in the contour, the phrase accent stretches to the beginning of the final syllable of the phrase (Grice \& Baumann 2002:280).

While evidence for the existence of phrase accents in Icelandic has not previously been found, it has been argued that both high $(\mathrm{H} \%)$ and low $(\mathrm{L} \%)$ boundary tones occur. All possible combinations of the two bitonal pitch accents and the two boundary tones have been attested: $\mathrm{H}^{*} \mathrm{~L} \mathrm{~L} \%, \mathrm{H}^{*} \mathrm{~L} \mathrm{H} \%, \mathrm{~L}^{*} \mathrm{H} \mathrm{L} \%$ and $\mathrm{L}^{*} \mathrm{H} \mathrm{H} \%$ (Árnason 1998). According to Árnason (1998), L\% is used to mark finality, i.e. it is primarily used at the end of utterances (in both statements and simple yes/no-questions, see (7) above), while H\% signals non-finality. Accordingly, Árnason (1998:53-56) describes $\mathrm{H}^{*} \mathrm{~L}$ $\mathrm{L} \%$ as a typical sequence at the end of declarative utterances (see (7a)), while $\mathrm{L}^{*} \mathrm{H}$ $\mathrm{H} \%$ and $\mathrm{H}^{*} \mathrm{~L} \mathrm{H} \%$ occur utterance-internally, i.e. at the end of an Intonational Phrase preceding another Intonational Phrase in the same Utterance (see (8)). L*H L\% and $\mathrm{L}^{*} \mathrm{H} \mathrm{H} \%$ are used in yes/no-questions (see (9)). ${ }^{1}$

(8) Utterance-internal IP (adapted from Árnason 1998:55, 56)

a. Pott Jón sé kominn, vitum við ekkert um Maríu.

\begin{aligned} & $\mathrm{L}^{*} \mathrm{H} \multicolumn{2}{c}{\mathrm{H} \%} \mathrm{H}^{*} \mathrm{~L}$ ! \\ & although Jón is come know we nothing about María \end{aligned}

'Although Jón has arrived, we know nothing about María.'

b. Jón er skemmtilegur, en ...

$\mathrm{H}^{*} \mathrm{~L} \quad \mathrm{H} \%$

Jón is pleasant but

(9) Yes/no-questions (adapted from Árnason 1998:54, 56)

a. Er Jón kominn, eða verð ég að hringja til hans?

$\mathrm{L}^{*} \mathrm{H} \quad \mathrm{L} \%$

is Jón come or must I to ring to him

'Has Jón arrived, or do I have to phone him?' 
b. Eigum við að koma til Nönnu?

$\mathrm{L}^{*} \mathrm{H} \mathrm{H} \%$

are we to come to Nanna

'Should we go and see Nanna?'

It is evident from the example in (9b) that $\mathrm{H} \%$ is not only used to indicate nonfinality. Rather, it is also possible for $\mathrm{H} \%$ to occur utterance-finally, here at the end of a yes/no-question.

Across Intonational Phrases, downstep has been described, such that later pitch peaks are lower than earlier ones (Árnason 1998; Dehé 2006). This holds in sequences of $\mathrm{L}^{*} \mathrm{H}$ as well as sequences of $\mathrm{H}^{*} \mathrm{~L}$ accents, and also in combinations of the two.

The aim of the present paper is to shed new light on the Icelandic tone inventory and tonal contours. It will be shown that along with the two bitonal pitch accents already observed in the literature, Icelandic has two monotonal pitch accents $\left(\mathrm{H}^{*}\right.$ and $\mathrm{L}^{*}$ ). The evidence is based mainly on the timing of the pitch movement after the starred tone, which occurs on the immediately adjacent syllable in bitonal, but not in monotonal accent types. Evidence will further be provided for two phrase accents (L- and H-), along with the two boundary tones. Phrase accents may be associated with secondarily stressed syllables. Finally, it will be shown that along with downstep, Icelandic also has upstep across Intonational Phrases. Upstep may occur in neutral declaratives and in utterances with final narrow focus.

The remainder of the article is organized as follows. Section 2 provides information on the sources and treatment of the data the analysis is based on. The data analysis in section 3 starts with a description of the patterns observed in neutral declaratives (section 3.1). Section 3.2 looks at declarative utterances with narrow focus. Section 3.3 addresses deaccenting and given information. Section 3.4 focuses on the discussion of phrase accents and provides evidence for the existence of $\mathrm{H}$ - and L-. Section 3.5 deals with downstep and upstep in Icelandic. Question intonation is addressed in section 3.6. A final discussion and summary are offered in section 4 .

\section{DATA}

The present study is based on data from three sources, two of which are experimental reading studies.

\subsection{The reading studies: materials}

For the purpose of the first reading study (Study 1), question-answer pairs were designed such that the question established the context for the answer sentence. The answer sentences exhibited either broad focus (neutral declaratives) or narrow focus on one of the following constituents: direct object (DO), indirect object (IO) or verb phrase (VP) consisting of a verb and at least one object. In addition, three listings as 
exemplified in (10e) were part of the materials. Overall, the list of items contained 27 target items: 5 neutral declaratives, 10 DO focus, 7 IO focus, and 5 VP focus, and the three listings. Examples are given in (10).

a. Neutral declarative (broad focus)

Q: (Hvað gerðist? 'What happened?')

A: Einar gaf Ásu appelsínu.

Einar gave Ása orange

'Einar gave Ása an orange.'

b. Direct object focus

Q: (Hvað fann Ásta? 'What did Ásta find?')

A: Ásta fann littla kettlinginn

Ásta found little kitten.DEF

'Ásta found the little kitten.'

c. Indirect object focus

Q: (Hverjum gaf Hildur eplið? 'To whom did Hildur give the apple?')

A: Hildur gaf Ástu eplið.

Hildur gave Ásta apple.DEF

'Hildur gave the apple to Ásta.'

d. VP focus

Q: (Hvað gerði Elísabet? 'What did Elísabet do?')

A: Elísabet borðaði banana.

Elísabet ate banana

'Elísabet ate a banana.'

e. Listed clauses

Gísli borðar epli, Elísabet borðar appelsínu, Elín borðar

Gísli eats apple Elísabet eats orange Elín eats

banana.

banana

'Gísli eats an apple, Elísabet eats an orange, Elín eats a banana.'

The materials of the second reading study (Study 2) were similar to the materials of the first study except that neutral declaratives were not preceded by questions (see (11a)), and there were no VP-focus sentences or listings. Instead, a number of target items exhibited subject focus or verb focus (see $(11 \mathrm{~b}, \mathrm{c})$ ). Overall, the data set consisted of 66 target items: 30 neutral declaratives, 16 DO focus, 8 subject focus, 8 IO focus, and 4 verb focus.

a. Neutral declarative (broad focus)

Snotri Englendingurinn keypti dýra bók. nice-looking English.person.DEF bought expensive book

'The nice-looking Englishman bought an expensive book.' 
b. Subject focus

Q: (Hver gaf Elínu appelsínu? 'Who gave Eileen an orange?')

A: María gaf Elínu appelsínu.

María gave Elín orange

c. Vfocus

'María gave Elín an orange.'

Q: (Hvað gerði María við söguna? 'What did María do with the story?')

A: María skrifaði söguna upp.

María wrote story.DEF up

'María wrote the story up.'

\subsection{The reading studies: participants, apparatus and procedure}

The first reading study was carried out in the spring of 2004 in the anechoic chamber at University College London, Department of Phonetics and Linguistics, with five female native speakers (S101-S105) of Icelandic. The materials of the second study were recorded in June 2004 in a quiet, closed room at the University of Iceland in Reykjavík with 12 native speakers of Icelandic (3 male, 9 female; S201-S212). All speakers were naïve as to the aim of the study. Their participation was voluntary. The target items were presented to the participants individually on a computer screen using Microsoft PowerPoint. They appeared on mouse-click, with the question in question-answer pairs preceding the answer. The participants were instructed to familiarize themselves with the items before reading them out loud, and to produce each sentence as naturally as possible at a normal speech rate. For question-answer pairs, both questions and answer sentences were read by the participants. The list of target items was preceded by four practice items in Study 1 and five practice items in Study 2. The practice items were similar in make-up to the target items. In Study 1, all practice items were question-answer pairs, while in Study 2, two of the five practice items were question-answer pairs. The target list was pseudo-randomized such that one focus type did not occur more than two times in an uninterrupted sequence. All utterances were recorded and later digitized into individual sound files using Audacity 1.1.3 and Cool EditTM96 software. Overall, 150 items were produced by the five participants of reading Study 1, and 792 items were produced by the twelve speakers in reading Study 2.

\subsection{The children's story Siggi og Stína}

The third data source, which complemented the experimental materials, was the Icelandic children's story Siggi og Stína, read and recorded by a trained female speaker (S301) in a colloquial way. It was originally tape-recorded for use as a comprehension exercise in language teaching. At the time of the recording, the speaker did not know that it would be used for any other purpose than her intended 


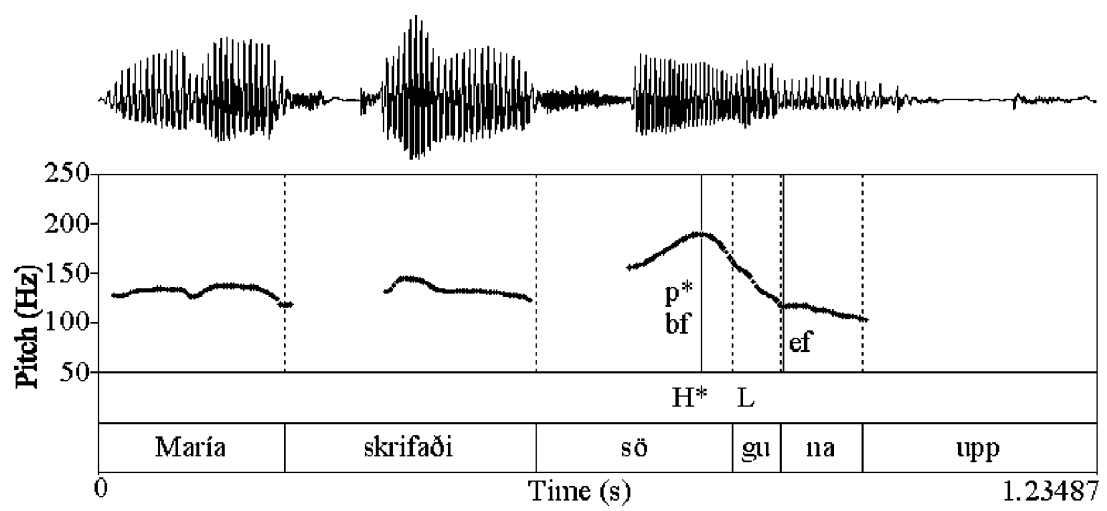

Figure 1. Target $\mathrm{H}^{*} \mathrm{~L}$ : Fo peak location in the accented syllable sö-, end of F0 fall after $\mathbf{H}^{*}$. Lower tier: segmental annotation; speaker S203, male; María skrifaði söguna upp 'María wrote the story up'.

one. The recording was provided on tape by the speaker and was digitized into individual sound files for the purpose of linguistic analysis.

\subsection{Data treatment}

All target items underwent an auditory and an instrumental analysis. The auditory analysis helped to identify location and type of perceived pitch accents. The instrumental analysis was done in PRAAT (Boersma 2001; Boersma \& Weenink 2008). In order to specify the pitch accent type, the following measurements were taken:
p* F0 peak location in the accented syllable for $\mathrm{H}^{*}(\mathrm{~L})$ pitch accents
$\mathrm{v}^{*} \quad \mathrm{~F} 0$ valley location in the accented syllable for $\mathrm{L}^{*}(\mathrm{H})$ pitch accents
bf beginning of $\mathrm{F} 0$ fall after $\mathrm{H}^{*}$
ef end of $\mathrm{F} 0$ fall after $\mathrm{H}^{*}$
br beginning of $\mathrm{F} 0$ rise after $\mathrm{L}^{*}$
er end of $\mathrm{F} 0$ rise after $\mathrm{L}^{*}$

An example is given in figure 1 . The first uninterrupted vertical line is marked $\mathrm{p}^{*}$ and relates to the F0 peak in the accented syllable $s \ddot{o}$-. This is also where the F0 fall begins. The second uninterrupted vertical line marks the end of the $\mathrm{F} 0$ fall after $\mathrm{H}^{*}$, i.e. a change in pitch direction. The lower tier and the dashed vertical lines provide the segmental annotation. The pitch accent in this particular example is analysed as $\mathrm{H}^{*} \mathrm{~L}$. The trailing tone, i.e. the fall after $\mathrm{H}^{*}$, is completed on the syllable - $g u$-, which immediately follows the prominent one. 

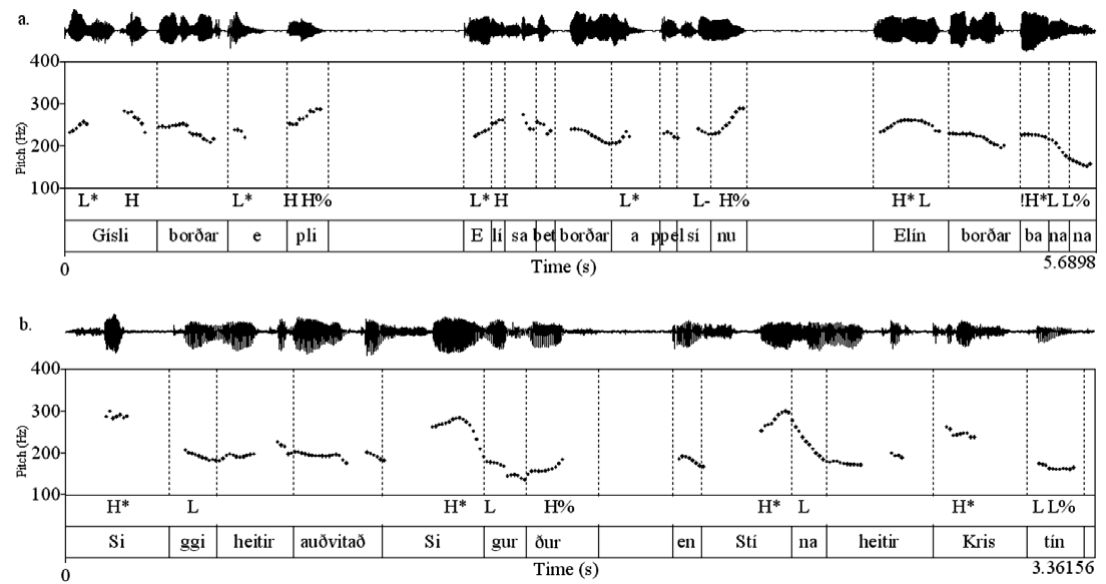

Figure 2. Tonal contours in declaratives: $L^{*} H H \%$ and $H^{*} L H \%$ marking continuation, $H^{*} L$ L\% marking finality. Panel a: speaker S101, female; panel b: from Siggi og Stína; speaker S301, female.

\section{ANALYSIS}

\subsection{Neutral declaratives ${ }^{2}$}

As mentioned above, normal sentence stress is rightmost (see (5a)). In the examples in (13) prominence falls on appelsinu and bók, respectively. Due to the word stress rule in (1), the pitch accent falls on the first syllable (a-) of appelsinu in (13a) and on monosyllabic bók in (13b).

\section{a. María gaf Elínu appelsínu. María gave Eileen orange}

'María gave Eileen an orange.'
b. Snotri útlendingurinn keypti dýra bók. nice.looking foreigner.DEF bought expensive book 'The nice looking foreigner bought an expensive book.'

Árnason's (1998) observations that (i) H\% marks continuation while L\% marks finality, and that (ii) both $\mathrm{L}^{*} \mathrm{H} \mathrm{H} \%$ and $\mathrm{H}^{*} \mathrm{~L} \mathrm{H} \%$ occur utterance-internally to mark prominence followed by an IP-boundary are readily confirmed in the present data. This is illustrated by the listing example in (14a) and by the coordination example from Siggi og Stína in (14b), plotted in figure 2a and figure 2b, respectively. The three listed clauses in (14a), figure 2a are each in a separate IP. The first IP (Gísli borðar epli) has a nuclear $\mathrm{L}^{*} \mathrm{H}$, where $\mathrm{L}^{*}$ falls on the stressed first syllable of epli and the trailing tone continues on the second syllable of epli. The H\% terminating this IP indicates continuation. The second IP (Elísabet borðar appelsínu) also ends in $\mathrm{H} \%$ 


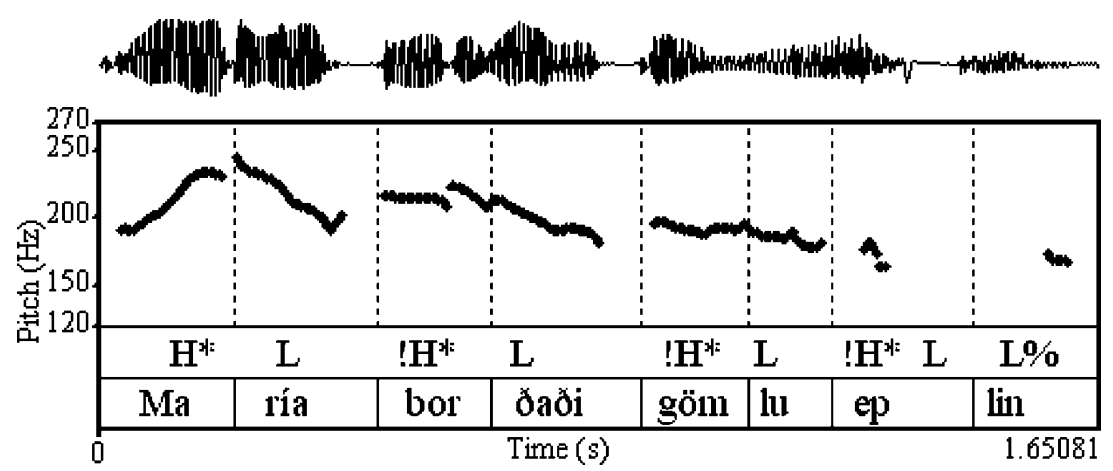

Figure 3. Downstep in neutral declarative; speaker S205, female.

indicating continuation. ${ }^{3}$ The third/last IP (Elín borðar banana) has a nuclear $\mathrm{H}^{*} \mathrm{~L}$, where the first syllable of banana carries $\mathrm{H}^{*}$ and the $\mathrm{L}$ trailing tone is completed on the second syllable of banana. This IP is terminated by L\% indicating finality. The coordinated utterance in figure $2 b$ is made up of two IPs, the first of which ends in $\mathrm{H}^{*} \mathrm{~L} \mathrm{H} \%$ where $\mathrm{H} \%$ indicates continuation, while the second IP terminates in $\mathrm{H}^{*} \mathrm{~L}$ L\% with $\mathrm{L} \%$ indicating finality. ${ }^{4}$

a. Gísli borðar epli, Elísabet borðar appelsínu, Elín borðar

Gísli eats apple Elísabet eats orange Elín eats banana.

banana

'Gísli eats an apple, Elísabet eats an orange, Elín eats a banana.'

b. Siggi heitir auðvitað Sigurður en Stína heitir

Siggi is.called of.course Sigurður and Stína is.called

Kristín.

Kristín

'Siggi’s real name is of course Sigurður and Stína's name is Kristín.'

Short utterances are typically produced with a sequence of downstepped $\mathrm{H}^{*} \mathrm{~L}$ pitch accents (see (15a) and figure 3), or with one or more $\mathrm{L}^{*} \mathrm{H}$ pitch accents followed by one or more $\mathrm{H}^{*} \mathrm{~L}$ accents (see (15b)), the final pitch accent being the most prominent one (see also Árnason 1998). Note that monosyllabic verbs were not prominent except when narrowly focused.

(15) Frequently used pitch accent sequences in Icelandic declaratives

a. Series of downstepped $\mathrm{H}^{*} \mathrm{~L}$ pitch accents (see figure 3 )

María borðaði gömlu eplin.

$\mathrm{H}^{*} \mathrm{~L} \quad$ ! $\mathrm{H}^{*} \mathrm{~L} \quad$ ! $\mathrm{H}^{*} \mathrm{~L} \quad ! \mathrm{H}^{*} \mathrm{~L} \mathrm{~L} \%$

María ate old apple.DEF

'María ate the old apple.' 


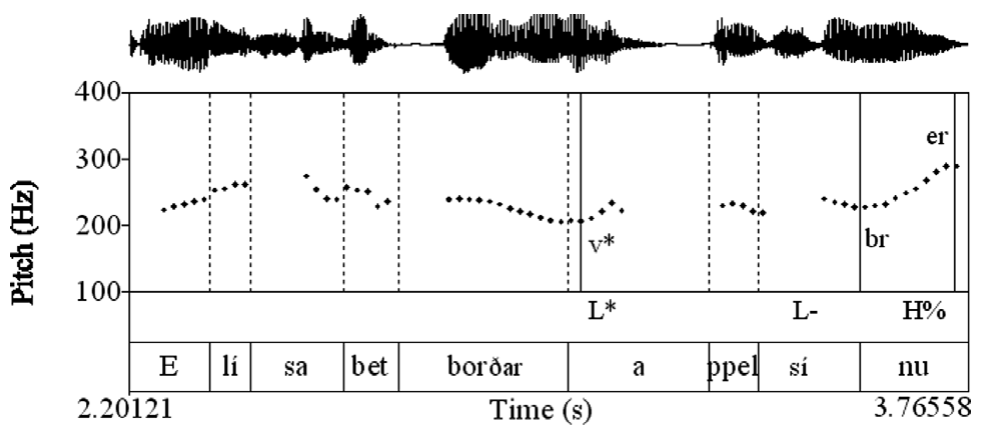

Figure 4. Monotonal pitch accent $\mathrm{L}^{*}$ : Elísabet borðar appelsínu (second part of listing in (14a)/figure 2a); speaker S101, female.

b. (One or more) $\mathrm{L}^{*} \mathrm{H}$ followed by (one or more) $\mathrm{H}^{*} \mathrm{~L}$

María gaf Elínu appelsínu.

b1. $\mathrm{L}^{*} \mathrm{H} \quad \mathrm{L}^{*} ! \mathrm{H} \quad$ ! $\mathrm{H}^{*} \mathrm{~L} \mathrm{~L} \%$

b2. $\mathrm{L}^{*} \mathrm{H} \quad$ ! $\mathrm{H}^{*} \mathrm{~L} \quad \mathrm{H}^{*} \mathrm{~L} \mathrm{~L} \%$

María gave Elín orange

'María gave Elín an orange.'

Example (14a) also provides phonetic evidence in favour of a monotonal $\mathrm{L}^{*}$ as part of the Icelandic tonal inventory beside $\mathrm{L}^{*} \mathrm{H}$. Instead of $\mathrm{L}^{*} \mathrm{H}$, we find $\mathrm{L}^{*}$ on appelsinu in the second conjunct. The crucial difference between bitonal and monotonal pitch accents in the Icelandic grammar, and thus substantial evidence for the presence of monotonal pitch accents, lies in the presence vs. absence of the trailing tone as realized on the starred syllable or on the syllable immediately following it. Specifically, this is the (timing of the) rise after $\mathrm{L}^{*}$ and the fall after $\mathrm{H}^{*}$. Recall that in Icelandic, a trailing tone belonging to a bitonal pitch accent must be realized on the same syllable that bears the stressed tone or on the syllable adjacent to it. Figure 4 zooms in onto the second conjunct of example (14a)/figure $2 \mathrm{a}$. The first syllable of appelsínu bears an $\mathrm{L}^{*}$ pitch accent, but there is no immediate pitch rise on the same or adjacent syllable that would serve as evidence for a bitonal pitch accent. The final F0 rise on appelsinu starts at the beginning of the unstressed final syllable - $n u$ and is towards the high boundary tone at the end of the IP. ${ }^{5}$ (The L- phrase accent indicated in figure 4 will be discussed in section 3.4 below.)

A similar case can be made for $\mathrm{H}^{*} \mathrm{~L}$ vs. $\mathrm{H}^{*}$. For example, under neutral focus and final narrow focus, the sentence María gaf Elínu appelsínu 'María gave Elín an orange' occurs most frequently with a sentence-final, nuclear $\mathrm{H}^{*} \mathrm{~L}$ pitch accent. $\mathrm{H}^{*}$ associates to the first, lexically stressed syllable $a$ - of appelsinu, followed by a low trailing tone completed on the second syllable of appelsínu. L\% terminates the IP. In some cases, however, there is no immediate pitch fall from the F0 peak on the same 
or immediately following syllable that would serve as evidence for a bitonal $\mathrm{H}^{*} \mathrm{~L}$ pitch accent. The pitch is sustained on a high level and the fall delayed until the very last syllable, $-n u$, where it is towards the IP-final L\% (see the discussion of (19) and note 8 in section 3.4 below).

Neither of the two monotonal pitch accent types is particularly frequent in the data, but both types can be observed in neutral declaratives (as illustrated in figure 4 for $\mathrm{L}^{*}$ ) as well as in declaratives with narrow focus and in questions. Note once again that the assumption of the two monotonal pitch accents is based on phonetic evidence. Whether or not a phonological contrast between bitonal and monotonal accents can be established remains an important topic for future research.

\subsection{Declaratives with narrow focus}

Like many other languages, Icelandic makes use of pitch accents to mark the focus of the utterance (Árnason 1985, 1998; Dehé 2006); see (5) above. Some of the materials the present work is based on were specifically designed to address research questions related to focus structures in Icelandic (see section 2.1 above). In the data used here, a focused constituent is one that corresponds to a $w h$-constituent in a given question. The examples discussed in this section are given in (16).

a. Subject focus

Q: (Hver gaf Elínu appelsínu? 'Who gave Elín an orange?')

A: [María $]_{\text {Foc }}$ gaf Elínu appelsínu.

María gave Elín orange

'María gave Elín an orange.'

b. Indirect object focus

Q: (Hverjum sendi Níels böggul? 'To whom did Níels send a parcel?')

A: Níels sendi $[\text { Maríu }]_{\text {Foc }}$ böggul.

Níels sent María parcel

'Níels sent María a parcel.'

c. Direct object focus

Q: (Hvað skrifaði María upp? 'What did María write up?')

A: María skrifaði [söguna] $]_{\text {Foc }}$ upp.

María wrote story.DEF up

'María wrote the story up.'

d. Verb focus

Q: (Hvað gerði María við söguna? 'What did María do with the story?')

A: María [skrifaði $]_{\mathrm{Foc}}$ söguna $[\mathrm{upp}]_{\mathrm{Foc}}$.

The examples in (16c, d) are compared in figure 5. The locus of the nuclear pitch accent $\mathrm{H}^{*} \mathrm{~L}$ shifts according to the position of the focus. In (16c), represented in figure 5a, it falls on the focused direct object söguna. (16d), represented in figure 5b, is 

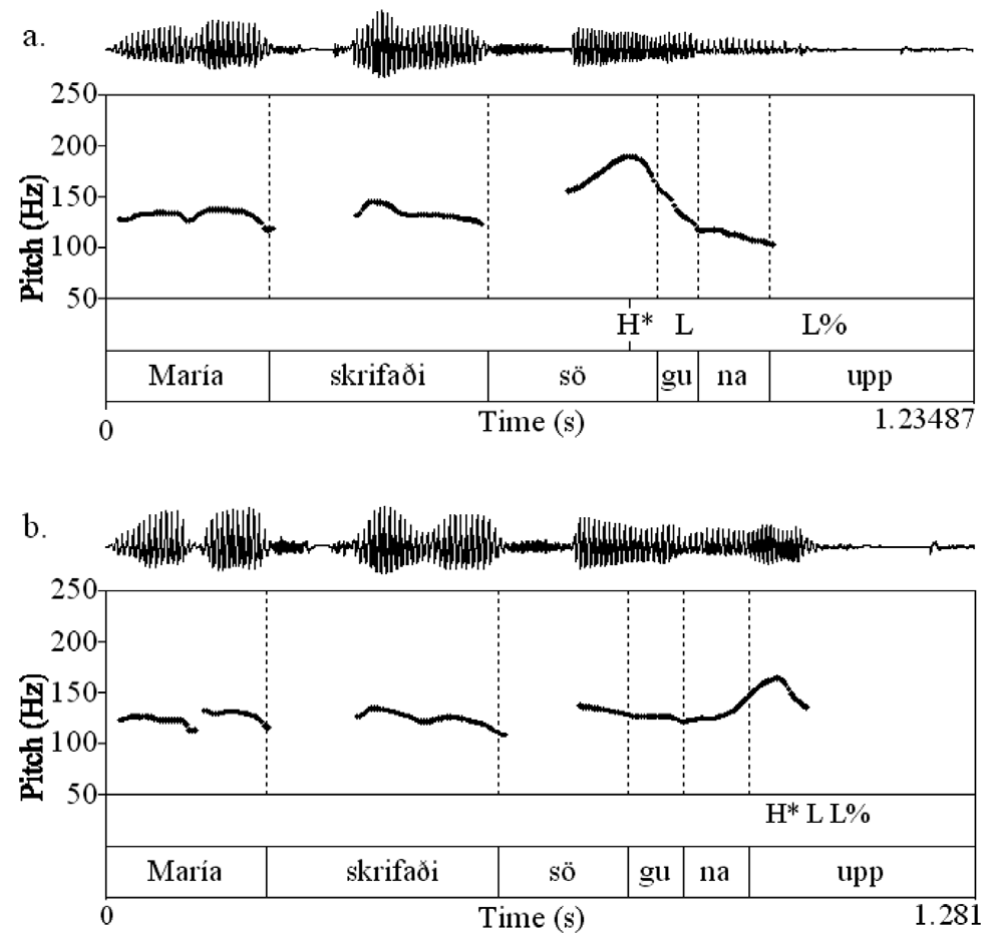

Figure 5. Narrow focus marked by $\mathbf{H}^{*} \mathrm{~L}$ pitch accent. Panel a: direct object focus (söguna); panel b: verb focus (skrifaði upp); speaker S203, male; examples (16c) and (16d), respectively.

an example of verb focus. Since the verb consists of the verb skrifaði and the verbal particle upp following the object söguna, the final particle functions as the focus exponent, hence it carries the main pitch accent.

$\mathrm{L}^{*} \mathrm{H}$, too, is used to mark narrow focus. This is illustrated in figure 6, representing narrow focus on the indirect object Maríu in panel a (example (16b)), and on the subject María in panel b (example (16a)).

It is worth noting that both accent types occur in all focus positions. They seem to be equally felicitous to mark a focused constituent. In addition to the fact that both accent types occur quite frequently across the focus data, this claim is based on the intuition of one of my informants. He was given the context question, then presented with a pair of lexically and syntactically identical sentences, one containing $\mathrm{L}^{*} \mathrm{H}$ associated with the focus constituent, the other one, $\mathrm{H}^{*} \mathrm{~L}$. No difference in interpretation was felt. Rather, both types were equally acceptable to convey the same message. Moreover, along with the two bitonal pitch accents, both monotonal pitch accents, $\mathrm{H}^{*}$ and $\mathrm{L}^{*}$, are attested as markers of narrow focus in the data. What is clearly obvious from the data is that $(5 b)$ holds, i.e. that focus is prominent. Narrow focus has a nuclear pitch accent across the data studied here. Future research will 

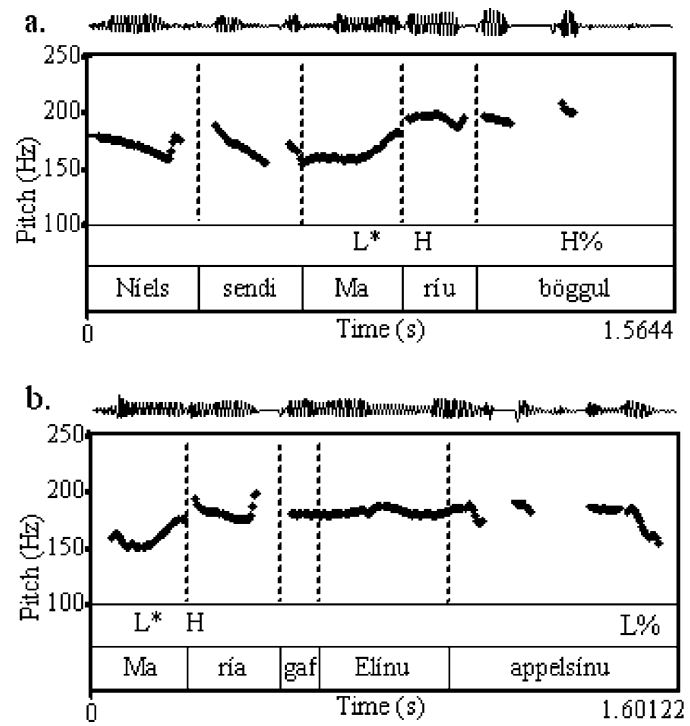

Figure 6. Narrow focus marked by $L^{*} H$ pitch accent. Panel a: indirect object focus (Maríu, example (16b)); panel b: subject focus (María, example (16a)); speaker S209, female.

have to show in what way the different pitch accent types are related to different shades of intonational meaning.

Since all four pitch accent types occur to mark narrow focus, a unique focusmarking sequence (such as the $\mathrm{L}^{*} \mathrm{H}$ - sequence in Bengali, see Hayes \& Lahiri 1991) cannot be identified at this stage of research. However, what is striking is that focusmarking $\mathrm{L}^{*} \mathrm{H}$ accents, in particular early on in an utterance, have a preference to co-occur with following high tones (both later pitch accents and edge tones), and that these utterances are exempted from downstep. In other words, after an $\mathrm{L}^{*} \mathrm{H}$ focus accent, regardless of its position, the pitch often forms a high plateau on post-nuclear material until the end of the utterance is reached. This can be seen in figure 6 . In panel a, showing focus on the indirect object Mariu, the pitch contour stays at the high level reached on the focused constituent and ends in $\mathrm{H} \%$. In panel $\mathrm{b}$, we have a nuclear rise on the focused subject Maria, and the contour stays at this high level until the very last syllable, where the contour falls towards $\mathrm{L} \%$.

The pitch patterns in declarative sentences and in utterances containing narrow focus and the resulting differences can be summarized as follows. Declaratives are typically realized with a sequence of downstepped $\mathrm{H}^{*} \mathrm{~L}$ pitch accents, or a sequence of one or more $\mathrm{L}^{*} \mathrm{H}$ pitch accents followed by one or more $\mathrm{H}^{*} \mathrm{~L}$ accents. According to (5), the final pitch accent is the most prominent one. Narrow focus is marked by pitch accents, most frequently a bitonal one. In contrast to neutral declaratives, pitch peaks in focus-marking pitch accents may be exempted from downstep (see section 3.5 below). A non-final $\mathrm{L}^{*} \mathrm{H}$ focus accent is preferably followed by a stretch of high 
pitch. The difference between neutral declaratives with initial $\mathrm{L}^{*} \mathrm{H}$ pitch accent(s) (such as (15b)) and utterances with non-final narrow focus marked $\mathrm{L}^{*} \mathrm{H}$ (e.g. figure 6) thus lies in the pitch pattern after the $\mathrm{L}^{*} \mathrm{H}$ pitch accent. While pre-nuclear $\mathrm{L}^{*} \mathrm{H}$ in neutral declaratives triggers downstep and is typically followed by one or more $\mathrm{H}^{*} \mathrm{~L}$ pitch accents, $\mathrm{L}^{*} \mathrm{H}$ marking non-final narrow focus is followed by a high pitch plateau stretching to the end of the utterance.

Before moving on to edge tones, I address the prosodic marking of given information in Icelandic in the next section.

\subsection{Deaccenting and given information}

It is generally assumed that in West Germanic languages, given or predictable information is deaccented, i.e. a word that might be expected to be accented fails to be accented in a context where the information that it conveys has already been mentioned before (see e.g. Ladd 1980, 1996; Cruttenden 1993). However, while prosodic attenuation has been linked to givenness (or activeness of the discourse referent; e.g. Lambrecht 1994:97), it is not necessary: given information may indeed be accented. A number of authors have thus distinguished between different degrees of givenness and the corresponding prosodic realization. For example, in work on English, Allerton (1978) distinguishes between 'unknown' (morphologically indefinite) and 'known' (morphologically definite) discourse referents. In terms of degrees of givenness and prosodic realization, this dichotomy translates into a four-way system of 'new' ('unknown'), 'semi-new', 'semi-given' and 'given' (all 'known') referents. New and semi-new information is associated with a nuclear fall, while semi-given information has a nuclear rise and given information is non-nuclear. More recently, Baumann \& Grice (2006) argue for German that degrees of 'given' or 'accessible' are reflected in the prosodic marking of the relevant constituent.

For Icelandic, Nolan \& Jónsdóttir (2001) carried out an experimental study using materials along the lines of (17). The target noun is in sentence-final position, i.e. the position that attracts neutral sentence stress (see (5a) above).

a. Type I: target $N$ is textually given

Ég gaf henni epli, en hún borðar ekki epli.

I gave her apple but she eats not apples

'I gave her an apple, but she doesn't eat apples.'

b. Type II: target $N$ is hypernym of textually given $N$

Ég gaf henni epli, en hún borðar ekki ávexti.

I gaveher apple but she eats not fruit

'I gave her an apple, but she doesn't eat fruit.'

c. Type III: target $N$ is new

Ég gaf henni epli, en hún vildi frekar fá appelsínu.

I gaveher apple but she wanted rather orange

'I gave her an apple, but she preferred an orange.' 
The target noun epli in Type I (see (17a)) is repeated from the first clause, thus textually given (see Allerton 1978 among many others). In Type II (see (17b)), the target noun ávexti is a hypernym of a preceding noun, and must, according to Nolan \& Jónsdóttir (2001) therefore be treated as given. ${ }^{6}$ The target noun appelsínu in Type III (see $(17 \mathrm{c})$ ) is neither textually nor semantically given and is thus treated as new (or: contrastive). Under the assumption that given information is deaccented, the target nouns in Types I and II would thus be predicted to be deaccented, while the target noun in Type III would be predicted to be prominent. An English version of the materials was read by four native speakers of Standard Southern British English, while the Icelandic materials were read by four native Icelandic speakers. The results confirmed the authors' predictions such that overall, the target nouns on Types I and II were deaccented in the English data, but were accented in all three types in Icelandic. Nolan \& Jónsdóttir (2001) conclude that given material is not necessarily deaccented in Icelandic. According to their study, then, it seems possible that Icelandic behaves more like languages such as Romanian and Italian (Ladd 1996:175-179; Cruttenden 1993) and Cairene Arabic (Hellmuth 2005, 2006), for which it has been shown that prominence patterns do not necessarily reflect givenness, i.e. that given material can resist deaccenting. However, Nolan \& Jónsdóttir (2001:193) maintain that there is no reason to assume that Icelandic content words require an accent regardless of information structure.

In the data analysed for the purpose of the present study, there is evidence both supporting and contradicting the assumption that given information resists deaccentuation. For illustration, consider the data in (18) from Study 1.

(18) a. (Q: Hverjum gaf Stéfan appelsínuna? 'To whom did Stéfan give the orange?')

A: Stéfan gaf $[\text { Elínu }]_{\text {Foc }}$ appelsínuna.

Stéfan gave Elín orange.DEF

'Stéfan gave the orange to Elín.'

b. (Q: Hverjum sendi Björg bæklinginn? 'To whom did Björg send the booklet?')

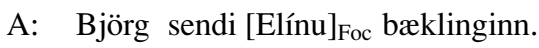

Björg sent Elín booklet.DEF

'Björg sent the booklet to Elín.'

c. (Q: Hverjum gaf Hildur eplið? 'To whom did Hildur give the apple?')

A: Hildur gave [Ástu $]_{\mathrm{Foc}}$ eplið.

Hildur gave Ásta apple.DEF

'Hildur gave the apple to Ásta.'

All three answer sentences exhibit indirect object focus. All other constituents are textually given since they are repeated from the directly preceding question. As outlined in section 2.1 above, the sentences were produced by five speakers. Across 


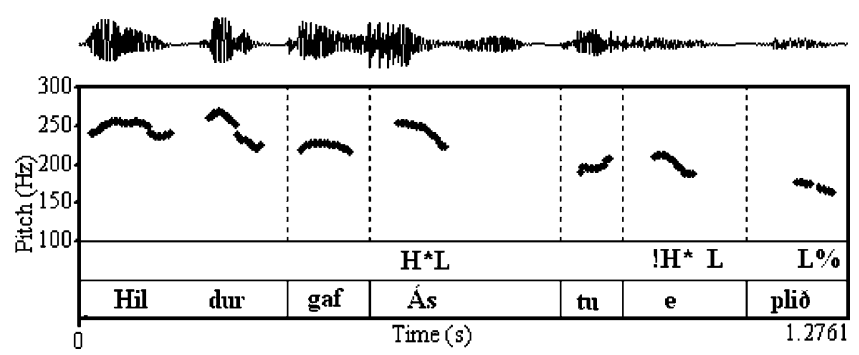

Figure 7. Accenting of textually given information (speaker S101, female): given information eplið fails to be deaccented.

all speakers and all three items, the focus on the indirect object was marked by a $\mathrm{H}^{*} \mathrm{~L}$ pitch accent. Of the five speakers, three speakers failed to deaccent the direct object (DO) appelsínuna in (18a), two speakers failed to deaccent the DO baklinginn in (18b), and two speakers failed to deaccent the DO eplið in (18c). In this data set, all post-focus pitch accents were of the same type as the focus-marking pitch accent and were downstepped with respect to the focus-marking pitch accent. Figure 7 represents sentence (18c), produced by speaker S201, with a focus-marking $\mathrm{H}^{*} \mathrm{~L}$ pitch accent on the indirect object $A s t u$ and a post-nuclear $! \mathrm{H}^{*} \mathrm{~L}$ pitch accent on the textually given direct object eplið following the focus accent.

Thus, the present data confirm that deaccenting is not obligatory in Icelandic, even if the relevant constituent is textually given as in the data in (18). The questions of under which circumstances given material fails to be deaccented and whether or not there are certain regularities have to be left to further research.

\subsection{Phrase accents}

In this section I will argue that along with high and low boundary tones, Icelandic has high (H-) and low (L-) phrase accents, too. As outlined in the introduction, phrase accents are edge tones which terminate the Intermediate Phrase and control the F0 between the last pitch accent and the phrase edge, and which seek to associate to a (secondarily) stressed syllable. They do not necessarily occur phrase-finally, but at some point after the final pitch accent of the relevant domain and before the boundary tone. If phrase accents can be related to secondary stress, compounds and polysyllabic words in the data present a good starting point for the discussion of phrase accents.

Recall (from section 1) that the regular stress pattern in Icelandic is Swsw. For example, the noun appelsina 'orange' has primary stress on the first syllable $a$-, and secondary stress on the third syllable, -sí-. The contour in figure $8 \mathrm{a}$ is repeated from figure 4 above, where the pitch accent was analysed as $\mathrm{L}^{*}$ due to the timing of the pitch movement after the starred tone on the stressed syllable. After the low starred tone, there is another low tonal target on the secondary stressed syllable, -si-, which 

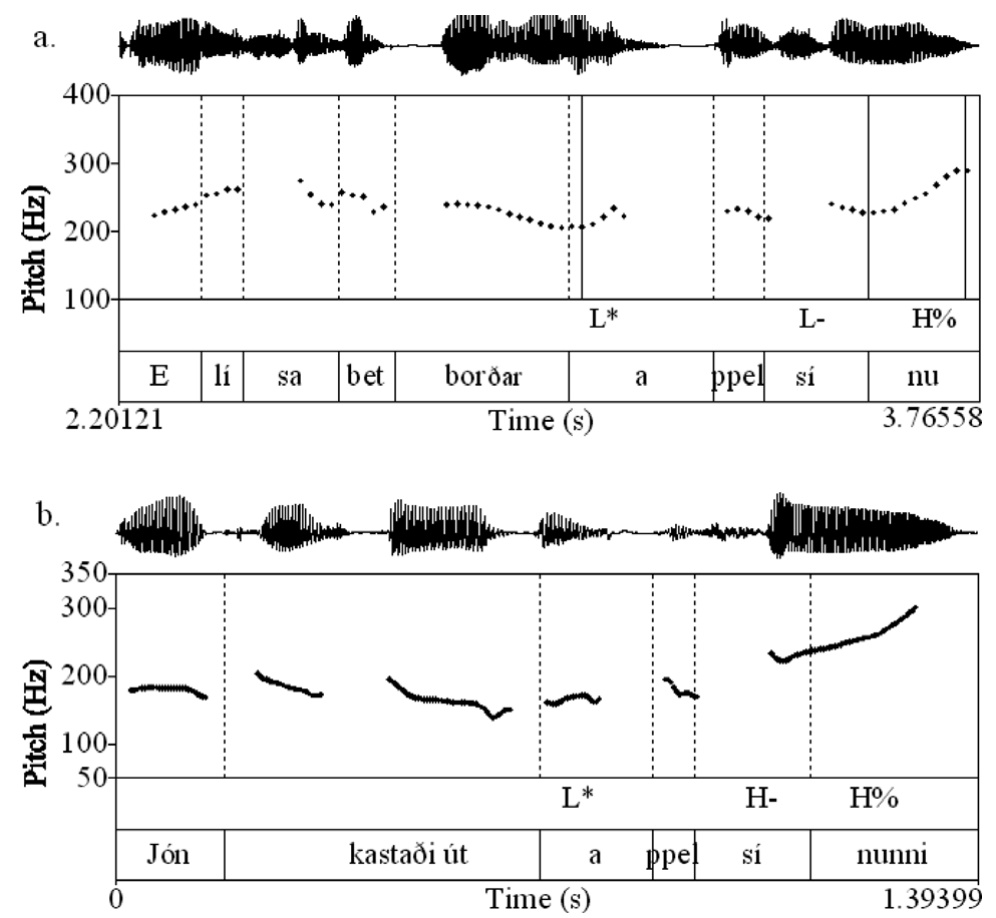

Figure 8. Phrase accent. Panel a: Elísabet borðar appelsínu 'Elísabet eats an apple' (second part of a listing consisting of three parts); speaker S101, female; panel b: Jón kastaði út appelsínunni 'Jón threw out the oranges'; speaker S207, female.

stretches to the beginning of the final syllable, where we observe a pitch rise towards a high boundary tone. This low target on -sí- can be analysed as an L- phrase accent. In figure $8 \mathrm{~b}$, on the other hand, the tonal target on the secondarily stressed syllable is a high one. Without the assumption of a phrase accent, the two contours in figure 8 would both be described as terminating in an $\mathrm{L}^{*} \mathrm{H} \%$ sequence associated with appelsínu/appelsínunni. This would ignore the difference between the two contours which lies in the tonal target on the secondarily stressed syllable, -si-. In other words, the phrase accent controls the F0 between the last pitch accent ( $\mathrm{L}^{*}$ in both contours) and the end of the IP (marked H\% in both cases), such that there is a low tonal target in figure $8 \mathrm{a}$, but a high tonal target in figure $8 \mathrm{~b}$. This tonal target associates to the syllable that carries secondary stress. The phrase accent thus captures the difference between the two contours. ${ }^{7}$

Similarly, the $\mathrm{H}^{*}$ pitch accent can be argued to occur in combination with a high phrase accent (H-). As discussed in section 3.1 above, the object noun appelsinu in (19) carries an $\mathrm{H}^{*}$ pitch accent. $\mathrm{H}^{*}$ is followed by another high tonal target on the secondarily stressed syllable, $-s i-$, which stretches to the beginning of the final 
syllable, $-n u$ and is followed by a fall towards the low boundary tone. This high target can be analysed as an $\mathrm{H}$ - phrase accent. $^{8}$

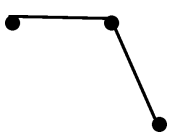

María gaf Elínu appel sí nu. 'María gave Elín an orange' $\mathrm{H}^{*} \quad \mathrm{H}-\mathrm{L} \%$

Looking at these data, the question presents itself whether we need bitonal pitch accents at all, or whether, for example, a $\mathrm{H}^{*} \mathrm{~L}$ pitch accent would best be analysed as a $\mathrm{H}^{*} \mathrm{~L}-(\mathrm{L} \%)$ sequence, to be distinguished from the $\mathrm{H}^{*} \mathrm{H}-\mathrm{L} \%$ sequence in (19) by the tonal target between starred syllable and domain edge. However, such an analysis would not be able to account for the timing difference in pitch movement after the starred tone. While a trailing tone must be completed at the end of the syllable immediately following the stressed one, the tonal target captured by the phrase accent is on the secondarily stressed syllable, which can never be adjacent to the primarily stressed one.

Future research will have to look more systematically at compounds and polysyllabic words in positions which would suggest the occurrence of a phrase accent, in order to see how phrase accents pattern, and if and how they are related to differences in interpretation. At this stage in the research, it seems that tonal contours in Icelandic utterances may be adequately described in a model that (i) makes a distinction between monotonal and bitonal pitch accents, (ii) includes the phrase accent T- (specified as $\mathrm{H}$ - and L-) associated with secondarily stressed syllables, and (iii) has final boundary tones $(\mathrm{H} \%$ and $\mathrm{L} \%)$.

\subsection{Downstep and upstep}

\subsubsection{Downstep}

As observed above, the most typical pattern in neutral declaratives is a downstepped sequence of $\mathrm{H}^{*} \mathrm{~L}$ pitch accents, followed by a low boundary tone. In a downstepped sequence of tones, later pitch peaks are lower than preceding ones. According to Beckman \& Pierrehumbert (1986), all bitonal accents trigger downstep of subsequent material.

For Icelandic, it has previously been argued that it has downstep such that in sentences with sequences of HL tones, later $\mathrm{H}$ peaks are lower than preceding ones (Árnason 1998, Dehé 2006; see (20a-c) and also (15) and figure 3 above). Árnason (1998:61) further notes that downstep is not limited to HL tones but may also occur in sequences of LH tones as they appear in what he calls 'closed' counts, illustrated in (20d), taken from his work. 


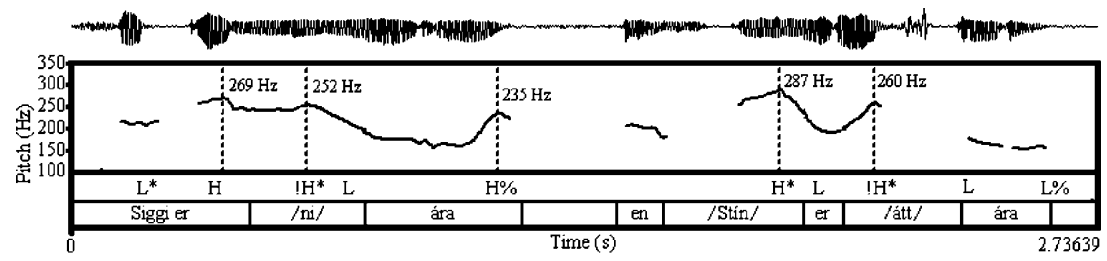

Figure 9. Downstep: Siggi er níu ára en Stína er áttu ára 'Siggi is nine years old and Stína is eight years old'; speaker S301, female.

a. Petta er gamall maður.

$\mathrm{H}^{*} \mathrm{~L} \quad ! \mathrm{H}^{*} \mathrm{~L} \quad ! \mathrm{H}^{*} \mathrm{~L} \mathrm{~L} \%$

this is old man

'This is an old man.'

b. Ég keypti kartöflur, sítrónur og banana.

$\mathrm{H}^{*} \mathrm{~L} \quad ! \mathrm{H}^{*} \mathrm{~L} \quad ! \mathrm{H}^{*} \mathrm{~L} \mathrm{~L} \%$

I bought potatoes lemons and bananas

'I bought potatoes, lemons and bananas.'

c. María gaf Hildi epli.

$\mathrm{H}^{*} \mathrm{~L} \quad$ ! $\mathrm{H}^{*} \mathrm{~L} \quad$ !H*$^{*} \mathrm{~L} \mathrm{~L} \%$

María gave Hildi apple

'María gave Hildi an apple'

d. Einn, tveir, prír, fjórir, fimm.

$\mathrm{L}^{*} \mathrm{H} \quad$ !L*H $\quad$ !L*H $\quad$ !L*H $\quad$ ! H*LL\%

one two three four five

The data under investigation here illustrate that downstep also occurs in mixed sequences of LH and HL tones. In the example plotted in figure 9 (from the story Siggi og Stína), this is illustrated for an utterance-initial $\mathrm{L}^{*} \mathrm{H} \mathrm{H}^{*} \mathrm{~L}$ sequence, a frequent pattern in Icelandic. The relevant pitch peaks are marked by dashed vertical lines and corresponding Hertz values. The trailing tone of the initial $\mathrm{L}^{*} \mathrm{H}$ accent is higher than the peak of the following $\mathrm{H}^{*} \mathrm{~L}$ accent, which in turn is higher than the high continuation-indicating boundary tone. Downstep of $\mathrm{H}^{*}$ on níu also serves the function of setting the prominent (starred) material off from the preceding nonprominent material (i.e. from the $\mathrm{H}$ trailing tone). ${ }^{9}$ The sequence of two $\mathrm{H}^{*} \mathrm{~L}$ accents in the second part of the utterance also exhibits downstep.

The same example also suggests the Intonational Phrase as the domain for downstep. Within one IP, later pitch peaks are downstepped as compared to earlier ones, while an IP boundary triggers pitch reset. The IP boundary separating ára and $e n$ is indicated by the high boundary tone and a structure-related pause of $254 \mathrm{~ms}$. Within the first IP, the peak on níu is downstepped relative to the preceding trailing tone, but it is in turn higher than the boundary tone terminating this IP. The beginning 


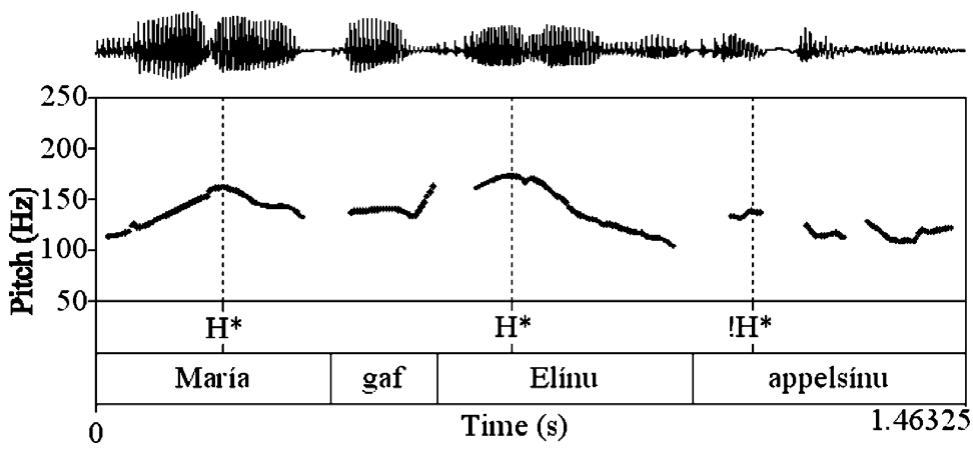

Figure 10. Downstep interrupted due to mid-focus position: María gaf $[\text { Elínu }]_{\text {Foc }}$ appelsínu 'María gave Elín an orange'; speaker S202, male (only pitch peaks are given).

of the new IP is marked by pitch reset (see the peak on the first syllable of Stina), and downstep can again be observed in this domain. Similarly, in the contour in figure $2 b$ (example (14b)) above, the two parts of the utterance (Siggi heitir auðvitað Sigurður and en Stína heitir Kristín, respectively) are separated by an IP boundary, indicated by the $\mathrm{H} \%$ boundary tone at the end of the first part and a pause of $240 \mathrm{~ms}$. Within the first part, the second pitch peak on the first syllable of Sigurður is downstepped relative to the first peak on Siggi. After the boundary, a pitch reset can be observed. The first peak on Stina is about as high as the peak on Siggi. The peak on Kristín is then downstepped, i.e. lower than the previous peak. Icelandic thus patterns with a number of related and unrelated languages, among them English and Dutch (see Gussenhoven 2004 and references there) and Chichewa (Kanerva 1990), in that reset typically occurs at IP boundaries.

Given that focus is marked by pitch accents, it comes as no surprise that cases with narrow focus in mid- or end-position are exempted from downstep. An example for focus in mid-position is given in figure 10. The sentence was produced with narrow focus on the indirect object Elínu, which is marked by a nuclear $\mathrm{H}^{*} \mathrm{~L}$ pitch accent. The subject is marked by the same accent type. The direct object appelsinu, which is assigned a separate intermediate phrase indicated by the glottal stop separating the two objects, also bears an audible $\mathrm{H}^{*} \mathrm{~L}$ pitch accent. The final peak is downstepped relative to the preceding ones, but downstep is interrupted by the peak on the focused constituent. (Note that here, as in figure 7 above, given information fails to be deaccented. Both the subject and the post-nuclear indirect object are accented, while the focused object is most prominent.) The vertical lines in figure 10 mark the pitch peaks of the $\mathrm{H}^{*} \mathrm{~L}$ pitch accents.

Similarly, it has been shown for Icelandic that in cases of final focus, downstep typically excludes the final pitch accent (Dehé 2006). This is in line with what has been observed for other languages, where downstep may exclude the (final) nuclear pitch 

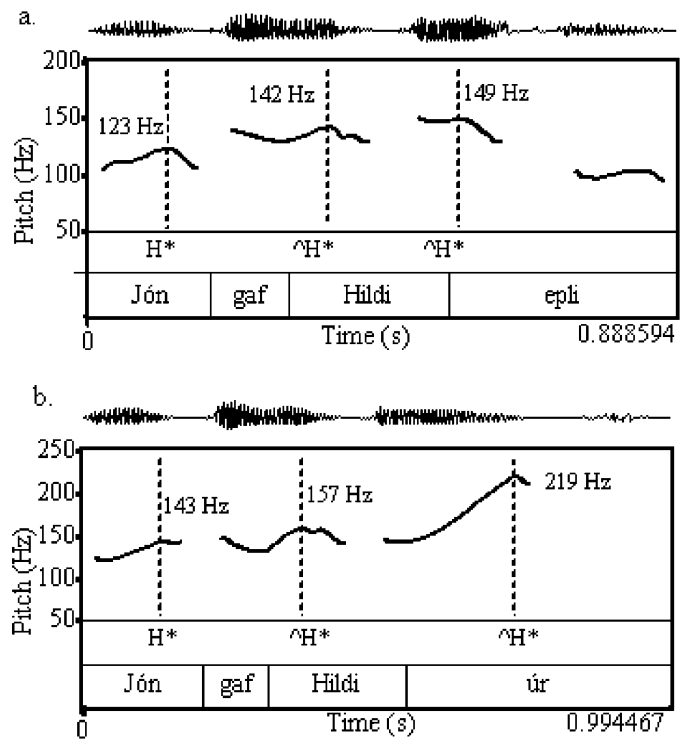

Figure 11. Upstep: Jón gaf Hildi epli/úr 'Jón gave Hildi an apple/a watch'. Panel a: narrow focus on epli; panel b: neutral declarative; speaker S212, male.

accent. For German, Grice \& Baumann (2002:279) note that reset usually takes place at a phrase boundary, but can also occur within a phrase, typically immediately before the nucleus. More precisely, after a sequence of downstepped tones the peak on the nuclear syllable is higher than previous peaks (see also Ladd 1983 and Gussenhoven 1984 for English and Dutch). Also for German, Féry (1993) argues that a later H tone which is at the same or a higher level than a preceding one is perceived as the focus. For English also, a final focused element has been found to have higher pitch than preceding downstepped peaks (Beckman \& Pierrehumbert 1986:298-299).

\subsubsection{Upstep}

Based on the evidence from the data studied here, I suggest that along with downstep, there is also upstep in Icelandic, such that later pitch peaks in tone sequences are higher than preceding ones. This is reminiscent of what has been observed for German (e.g. Grice \& Baumann 2002). Upstep is not to be confused with the absence of downstep in cases of final focus as just described. Rather, there are examples of continuous upstep, i.e. the second peak is higher than the first, and the third peak is higher than the second. This is illustrated in figure 11. Figure 11a is a case of narrow focus on the final constituent, i.e. the direct object epli, marked by an $\mathrm{H}^{*} \mathrm{~L}$ pitch accent. (As above, only the F0 peaks are indicated in the figure.) The first peak (on Jón) is lower than the peak on the first syllable of Hildi, which in turn is lower 
than the third peak on the first syllable of focused epli. The annotation follows the German ToBI system (GToBI, e.g. Grice \& Baumann 2002), which makes use of the diacritic ^ to mark upstep. The contour in figure $11 \mathrm{~b}$ serves as an example of upstep in neutral declaratives. Pitch peaks rise towards the final peak on úr.

In the data studied here, all cases of upstep occur either with final focus, as in figure 11a, or with neutral declaratives, as in figure 11b. The two cases have in common that the main prominence is sentence-final, either due to final focus, or due to the sentence stress rule which holds that under neutral focus, the rightmost constituent is the most prominent one (see (5) above). This suggests that upstep may span an Intonational Phrase, but that the last in a sequence of upstepped peaks is always the most prominent one.

\subsection{Question intonation}

In the present data, there is much variation regarding question intonation, which can only be briefly sketched here and will have to be further analysed in future work. One thing that clearly follows from the data is that the same pitch accents that we find in declaratives are also used in questions. Two examples for $\mathrm{L}^{*} \mathrm{H}$ in yes/no-questions were given in (9) in the introduction. According to Árnason (1998:56), L*H in yes/noquestions combines with $\mathrm{L} \%$ in a 'matter of fact' question, while together with $\mathrm{H} \%$ it yields 'friendly suggestions [calling for] an immediate reply'. For the purpose of the discussion in this section, question data were drawn both from the story Siggi og Stina and from the two reading studies.

As in neutral declaratives, main prominence in neutral questions is final. In the data under investigation, patterns for yes/no-questions and wh-questions were identical. The preferred nuclear question contour is $\mathrm{H}^{*} \mathrm{~L} \mathrm{~L} \%$. However, various combinations of pre-nuclear and nuclear pitch accents and edge tones can be found. Some attested examples are given in (21) for yes/no-questions, and in (22) for whquestions; see also figure 12 .

Unlike in declaratives, pitch peaks in questions are not usually downstepped. Instead, later pitch peaks are equally high or higher than earlier ones, regardless of whether they are trailing tones in a nuclear $\mathrm{L}^{*} \mathrm{H}$ or the starred tone in nuclear $\mathrm{H}^{*} \mathrm{~L}$. Having said that later peaks may be higher than earlier ones, this does not imply that we find upstep across IPs along the lines of figure 11.

The following examples provide an overview of the most frequent patterns observed in the data. (21) exemplifies yes/no-questions. (21a) is a sequence of (non-downstepped) pre-nuclear $\mathrm{H}^{*} \mathrm{~L}$ accents followed by nuclear $\mathrm{H}^{*} \mathrm{~L} \mathrm{~L} \%$. In (21b) (see also figure 12a), a pre-nuclear $\mathrm{H}^{*} \mathrm{~L}$ accent is followed by nuclear $\mathrm{L}^{*} \mathrm{H} \mathrm{L} \%$, a frequently found pattern. Both nuclear $\mathrm{H}^{*} \mathrm{~L}$ and nuclear $\mathrm{L}^{*} \mathrm{H}$ may also be combined with $\mathrm{H} \%$ (see (21c) and (21d), respectively). (22) illustrates a number of attested options in $w h$-questions. Comparing the frequently-used pitch accent sequences in 
a.

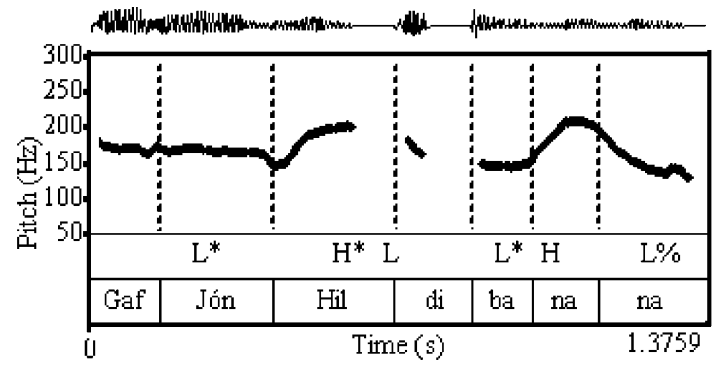

b.

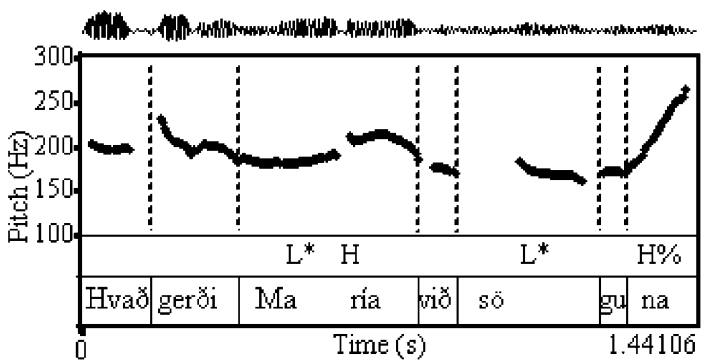

c.
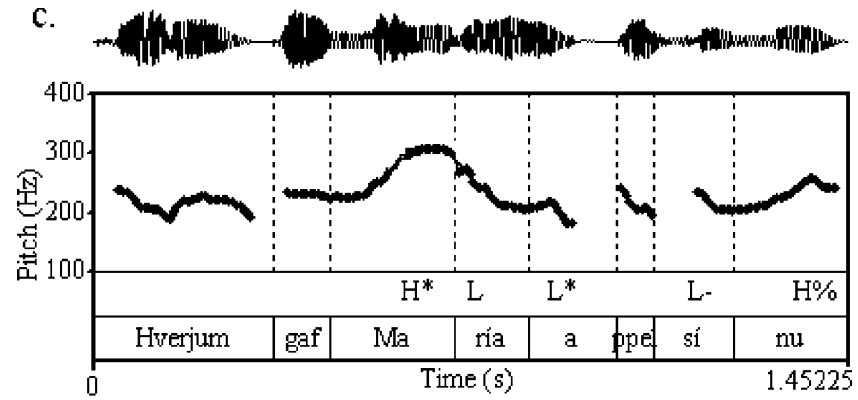

Figure 12. Selected patterns in yes/no-questions (panel a) and $w h$-questions (panels $b$ and c). Panel a (= (21b)): pre-nuclear $\mathrm{H}^{*} \mathrm{~L}$, nuclear $\mathrm{L}^{*} \mathrm{H} \mathrm{L} \%$ (Gaf Jón Hildi banana? 'Did Jón give Hildi a banana?'); speaker S209, female; panel b $(=(22 \mathrm{e}))$ : pre-nuclear $\mathrm{L}^{*} \mathrm{H}$, nuclear $\mathrm{L}^{*} \mathrm{H} \%$ (Hvað gerði María við söguna? 'What did María do with the story?'); speaker S205, female; panel c (= (22d)): pre-nuclear $H^{*} L$, nuclear $L^{*} L-H \%$ (Hverjum gaf María appelsínu? 'To whom did María give an orange?'); speaker S204, female.

neutral declaratives given in (15) above with (21) and (22), it may be noted that in neutral declaratives, $\mathrm{L}^{*}(\mathrm{H})$ pitch accents tend to precede $\mathrm{H}^{*}(\mathrm{~L})$ pitch accents, while in questions, $\mathrm{L}^{*}(\mathrm{H})$ tends to follow $\mathrm{H}^{*}(\mathrm{~L})$. Monotonal pitch accents are found in both pre-nuclear and nuclear position in questions; see, for example, figures $12 \mathrm{~b}$ and $12 \mathrm{c}$ for nuclear $\mathrm{L}^{*}$.

The plotted pitch tracks in figure 12 also show the absence of downstep in questions. Undoubtedly, there is a lot of variation in the intonation of Icelandic 
questions. Future research will have to show how the various contours relate to meaning.

(21) Yes/no-questions

$\mathrm{V}$ Subj Obj1 Obj2?

e.g. Gaf Jón Hildi banana? 'Did John give Hildi a banana?'
a.
$\left(\mathrm{H}^{*} \mathrm{~L}\right) \quad \mathrm{H}^{*} \mathrm{~L} \quad \mathrm{H}^{*} \mathrm{~L} \quad \mathrm{~L} \%$
b. $\quad\left(\mathrm{H}^{*} \mathrm{~L}\right) \mathrm{H}^{*} \mathrm{~L} \quad \mathrm{~L}^{*} \mathrm{H} \quad \mathrm{L} \%$ (see figure 12a)
c. $\quad\left(\mathrm{H}^{*} \mathrm{~L}\right) \mathrm{H}^{*} \mathrm{~L} \quad \mathrm{H}^{*} \mathrm{~L} \quad \mathrm{H} \%$
d. $\quad\left(\mathrm{H}^{*} \mathrm{~L}\right) \quad \mathrm{H}^{*} \mathrm{~L} \quad \mathrm{~L}^{*} \mathrm{H}$ H\%

(22) Wh-questions

\begin{tabular}{|c|c|c|c|c|}
\hline & Wh-word V & Subj & Obj? & \\
\hline e.g. & Hverjum gaf & María & appelsínu? 'To whom & $\ldots ? '$ \\
\hline a. & & $\mathrm{H}^{*} \mathrm{~L}$ & $\mathrm{H}^{*} \mathrm{~L} \quad(\mathrm{~L}-) \mathrm{L} \%$ & \\
\hline b. & & $\mathrm{H}^{*} \mathrm{~L}$ & $\mathrm{~L}^{*}(\mathrm{H}) \quad \mathrm{L} \%$ & \\
\hline c. & & $\mathrm{H}^{*} \mathrm{~L}$ & $\mathrm{H}^{*} \mathrm{~L} \quad \mathrm{~L}-\mathrm{H} \%$ & \\
\hline d. & & $\mathrm{H}^{*} \mathrm{~L}$ & $\mathrm{~L}^{*} \quad \mathrm{~L}-\mathrm{H} \%$ & (see figure $12 c$ ) \\
\hline e.g. & Нvað & María & söguna? & 'What did María do... .?' \\
\hline e. & & $\mathrm{L}^{*} \mathrm{H}$ & $\mathrm{L}^{*}(\mathrm{H}) \mathrm{H} \%$ & (see figure 12b) \\
\hline
\end{tabular}

\section{DISCUSSION AND OUTLOOK}

From the analysis of the Icelandic tone inventory, the following conclusions can be drawn.

Along with the two bitonal pitch accents previously described by Árnason (1998), Icelandic has the two monotonal pitch accents $\mathrm{H}^{*}$ and $\mathrm{L}^{*}$. The difference lies in the timing of the pitch movement after the starred tone. In bitonal pitch accents, it is immediately followed by a trailing tone, specifically a rise after $\mathrm{L}^{*}$ and a fall after $\mathrm{H}^{*}$, which is completed on the stressed or on the immediately adjacent syllable. While bitonal pitch accents are more frequent than monotonal ones, all pitch accent types occur across sentence types (neutral declaratives, declaratives with narrow focus, and questions) in pre-nuclear and nuclear position. This makes it difficult at this stage to establish a difference in intonational meaning.

Pitch accents are downstepped across declarative utterances, but usually not across interrogative utterances. As shown in section 3.5.1, the domain of downstep is the Intonational Phrase. Pitch accents marking narrow focus are exempted from downstep. Towards a final prominence, either due to neutral sentence stress or final focus, pitch peaks may also be upstepped across an Intonational Phrase.

Differences between Icelandic tunes can only be fully captured if the model includes a phrase accent T-, specified as L- or $\mathrm{H}-$, between final pitch accent and 
boundary tone. Docking sites for Icelandic phrase accents are syllables bearing secondary stress. In the present data, these are secondarily stressed syllables in polysyllabic words. Phrase accents have been identified at the end of Intonational Phrases, before final boundary tones. Future research on Icelandic prosodic phrasing will show whether Icelandic phrase accents can also be found to mark the end of an Intermediate Phrase followed by another Intermediate Phrase in the same Intonational Phrase.

Another important finding is the behaviour of $\mathrm{L}^{*}(\mathrm{H})$ accents in neutral declaratives and utterances with narrow focus (see section 3.2). While $\mathrm{L}^{*} \mathrm{H}$ in neutral declaratives triggers downstep and is typically followed by one or more $\mathrm{H}^{*} \mathrm{~L}$ pitch accents including the nuclear one, $\mathrm{L}^{*} \mathrm{H}$ marking narrow focus is often followed by a high plateau in the pitch contour on post-nuclear material, reaching a high boundary tone, or staying high until a final fall towards a low boundary tone. The difference in the contours is thus related to a difference in interpretation such that the sustained high pitch level, along with the pitch accent, marks the pre-final narrow focus.

Looking at the sequences of pitch accents and edge tones discussed in this study, it is striking that sequences in which all tones have identical specification (e.g. L*LL\%) are not attested. Future research will have to show whether this is the result of the Obligatory Contour Principle (OCP; Leben 1973, McCarthy 1986) at work, which in intonational phonology militates against sequences of identical tones. It is well known that, generally speaking, the OCP is relevant to intonational phonology. Bengali, for instance, is known to strictly follow the OCP (Hayes \& Lahiri 1991). In other languages, OCP violation is inevitable and thus occurs frequently. In the present data, at least one other phenomenon has been described which seems to obey the OCP: the downstepped $\mathrm{H}^{*} \mathrm{~L}$ pitch accent after a high trailing tone (see the discussion of figure 9 in section 3.5.1 above). However, the following observations go against the assumption that the OCP is obligatorily obeyed. Firstly, $\mathrm{T}^{*} \mathrm{~T}$ - sequences with identical specification seem to be allowed. In particular, $\mathrm{L}^{*} \mathrm{~L}$ - is illustrated in figure $8 \mathrm{a}$, followed by $\mathrm{H} \%$. Secondly, the trailing tone of a bitonal pitch accent may be identical to a following edge tone (e.g. figure 6a). Thirdly, T- T\% sequences seem to be allowed with identical specification (e.g. H- H\%, see figure $8 \mathrm{~b}$, but also note 7). Thus, the OCP is not strictly followed. Still, nuclear sequences in which all tones are identical are as yet unattested in Icelandic.

In Icelandic questions, speakers seem to have a choice between several available patterns. Future research on question intonation will have to show how meaning relates to intonation, not only regarding boundary tones (as discussed by Árnason 1998), but also the choice of pitch accents and combinations of pitch accents and edge tones.

Finally, a word is due on the nature of the data and the conclusions drawn for the tonal inventory of Icelandic. First, except for the focus contexts established in the experimental data, no discourse context was given in the data for the speakers to 
exploit. As a result, conclusions cannot be drawn as to intonational meaning other than the given/new distinction, or to speaker attitude or emotion. This is an obvious drawback related to the kind of data used here. In future research, a closer look is due at natural spoken language. It remains to be seen, for example, whether the phonetic distinction between monotonal and bitonal pitch accents is reflected in intonational meaning. Second, not only the material but also the actual task may be a downside in this respect. The reading task surely biased the speakers against a more natural way of producing utterances, despite the instructions, asking speakers to produce utterances in as natural a way as possible. Again, future studies will have to use more natural data, as elicited, for example, in different kinds of experimental tasks.

Despite this hedge, the present analysis has shed new light on Icelandic intonational phonology. Naturally, it also raises a number of interesting questions which will have to be addressed in future research on the topic. In particular, this concerns phonological contrasts between accent types identified on the basis of phonetic evidence alone. While the nature of the data investigated here does not reveal meaning-related differences, for example, between monotonal and bitonal pitch accents, insights in this respect will be gained from studies which systematically manipulate their target items with regard to shades of meaning beyond focus. What the present study does show is that all four pitch accent types are used to mark narrow focus.

Another important research question is that of the exact alignment and timing of tonal targets and their respective function. This concerns the timing of trailing tones used here to establish the phonetic difference between monotonal and bitonal pitch accents, but also the timing of starred tones and tonal targets preceding them. In particular, given that the timing of $\mathrm{H}^{*}$ is fairly late in contours such as those plotted, for example, in figure 1 (see the peak on $s \ddot{o}$-), figure 2 (see the peaks on $\mathrm{Si}$ and $S t i^{-}$), and figure 3 (see the peak on $M a$-), the question arises whether evidence can be found for a leading tone (e.g. L leading tone for $\mathrm{H}^{*}$ ). This would possibly result in an addition to the tonal inventory established here. Also, like elsewhere in intonation languages, the timing might be subject to various factors such as syllable type/structure, proximity and type of following prosodic boundaries, pre-nuclear vs. nuclear pitch accents, and intonational meaning.

Overall, while the paper provides new insights into the tonal grammar of Icelandic, a lot of research still needs to be done.

\section{ACKNOWLEDGEMENTS}

I would like to thank the following people who contributed in various ways and at various stages to the work presented here: Kristján Árnason, Thorhallur Eythorsson, Ragnheiður Guðmundsdottir, Carlos Gussenhoven, Jill House, Gunnar Hrafn Hrafnbjargarson, Jóhannes G. Jónsson, Aditi Lahiri, Tomas Riad, Moira Yip, 
and three anonymous reviewers for the Nordic Journal of Linguistics. Earlier versions of this paper were given in Konstanz in December 2006, and at the DGfS Annual Meeting in Siegen in February 2007. I wish to thank the audiences there for valuable feedback. I am particularly grateful to Aditi Lahiri and Frans Plank for giving me the opportunity to spend the winter term 2006/07 in Konstanz, where this paper was finally written up. The work presented here was in part supported by DFG individual research grant DE $876 / 1$ to the author.

\section{NOTES}

1. According to Árnason (1998:56), yes/no-questions ending in L\% 'sound more "matter of fact", while questions ending in $\mathrm{H} \%$ are more like "friendly suggestions [calling for] an immediate reply'.

2. For the present purpose, I will use 'neutral' synonymously with 'wide/broad focus'.

3. The phrase accent in the second conjunct in figure $2 \mathrm{a}$ will be discussed in section 3.4 below.

4. Note that the F0 peak in $\mathrm{H}^{*} \mathrm{~L}$ accents often appears to be timed fairly late in the stressed syllable (see e.g. the peaks associated with the first syllables of Sigurður and Stína in figure $2 b$ ). This raises the question of whether or not there is reason to assume an L leading tone. This issue will not be addressed here, but see also section 4 below.

5. There is in fact no audible pitch movement on the second syllable of appelsinu. What might look like pitch movement on the stressed and adjacent syllables is due to microprosodic effects, specifically the preaspirated plosive onset of the second syllable.

6. In previous literature, it has been shown that if a hyponym and hypernym occur in a sequence, a hyponym following its hypernym tends to be prominent, while a hypernym following the hyponym is deaccented (e.g. Allerton 1978:141; van Deemter 1999:7). In Nolan \& Jónsdóttir's (2001) experimental materials, the latter order was chosen. The hypernym ávexti in (17b) would thus be predicted to be deaccented in a language like English.

7. Notice the final rise on the last syllable in figure $8 \mathrm{~b}$. This rise is reminiscent of patterns observed in German that led to the assumption of an upstepped boundary tone ${ }^{\wedge} \mathrm{H} \%$. This boundary tone has been suggested to describe 'a sharp rise in the last syllable of the phrase, often to a point very high in the speaker's range' (Grice, Baumann \& Benzmüller 2005:68). In German, this kind of rise occurs at the end of neutral yes/no-questions, echo questions and follow-up questions. We do find it in Icelandic questions, too. However, at this stage in the research on Icelandic intonation, not enough data are available to back up this additional boundary tone in the tone inventory.

8. As noted by an anonymous reader, the $\mathrm{H}^{*} \mathrm{H}-\mathrm{L} \%$ combination indicated in (19) is not in line with MAE_ToBI. In MAE_ToBI, H-L\% is used to represent a high level contour, where L\% does not have an absolute low target, but a lower one than the upstepped $\mathrm{H} \%$ boundary tone (Beckman \& Elam 1997). The L tone in this combination is eliminated in GToBI '[s]ince using an $\mathrm{L}$ tone to represent mid or high pitch was considered counter-intuitive and difficult to learn' (Grice et al. 2005:68). Instead, GToBI uses H-\% for the high level contour. This allows the option of using H-L\% 'to describe a fall to low after a high plateau' (Grice et al. 2005:69). While this contour is not attested in Standard German, it is attested in Icelandic.

9. The final vowels in níu, Stína and áttu are deleted. In Icelandic, final unstressed vowels can be elided before initial vowels of the next word (Einarsson 1973:27; see Dehé 2008). 


\section{REFERENCES}

Allerton, D. J. 1978. The notion of 'givenness' and its relations to presupposition and to theme. Lingua 44, 133-168.

Árnason, Kristján. 1985. Icelandic word stress and metrical phonology. Studia Linguistica 39, 93-129.

Árnason, Kristján. 1987. The stress of prefixes and suffixes in Icelandic. In Kirsten Gregersen \& Hans Basbøll (eds.), Nordic Prosody IV: Papers from a Symposium, 137-146. Odense: Odense University Press.

Árnason, Kristján. 1998. Toward an analysis of Icelandic intonation. In Stefan Werner (ed.), Nordic Prosody: 7th Conference, Joensuu 1996, 49-62. Frankfurt, Berlin \& New York: Peter Lang.

Baumann, Stefan \& Martine Grice. 2006. The intonation of accessibility. Journal of Pragmatics 38, 1636-1657.

Beckman, Mary \& Gayle A. Elam. 1997. Guidelines for ToBI labelling; version 3.0. http://www.ling.ohio-state.edu/ tobi/ame_tobi/ (27 August 2008).

Beckman, Mary \& Janet Pierrehumbert. 1986. Intonational structure in Japanese and English. Phonology Yearbook 3, 255-309.

Boersma, Paul. 2001. PRAAT: A system for doing phonetics by computer. Glot International 5(9-10), 341-347.

Boersma, Paul \& David Weenink. 2008. Praat: Doing phonetics by computer (Version 5.0.04) [Computer program]. http://www.praat.org/ (10 February 2008).

Cruttenden, Alan. 1993. The de-accenting and re-accenting of repeated lexical items. Working Papers 41 (Department of Linguistics and Phonetics, Lund, Sweden) [Proceedings of an ESCA Workshop on Prosody, 27-29 September 1993, Lund], 16-19.

Deemter, Kees van. 1999. Contrastive stress, contrariety, and focus. In Peter Bosch \& Rob van der Sandt (eds.), Focus: Linguistic, Cognitive and Computational Perspectives, 3-17. Cambridge: Cambridge University Press.

Dehé, Nicole. 2006. Some notes on the focus-prosody relation and phrasing in Icelandic. In Gösta Bruce \& Merle Horne (eds.), Nordic Prosody: 9th Conference, Lund 2004, 47-56. Frankfurt, Berlin \& New York: Peter Lang.

Dehé, Nicole. 2008. To delete or not to delete: The contexts of Icelandic final vowel deletion. Lingua 118(5), 732-753.

Einarsson, Stefán. 1973. Icelandic: Grammar, Texts, Glossary (2nd edn.). Baltimore, MD: The John Hopkins University Press.

Féry, Caroline. 1993. German Intonational Patterns (Linguistische Arbeiten 285). Tübingen: Niemeyer.

Gårding, Eva. 1998. Intonation in Swedish. In Daniel Hirst \& Albert Di Christo (eds.), Intonation Systems: A Survey of Twenty Languages, 112-130. Cambridge: Cambridge University Press.

Grice, Martine \& Stefan Baumann. 2002. Deutsche Intonation und GToBI. Linguistische Berichte 191, 267-298.

Grice, Martine, Stefan Baumann \& Ralf Benzmüller. 2005. German intonation in autosegmental-metrical phonology. In Sun-Ah Jun, Prosodic Typology: The Phonology of Intonation and Phrasing, 55-83. Oxford: Oxford University Press.

GriceMartine, D. Robert Ladd \& Amalia Arvaniti. 2000. On the place of phrase accents in intonational phonology. Phonology 17(2), 143-185. 
Gussenhoven, Carlos. 1984. Stress shift and the nucleus. In Carlos Gussenhoven, On the Grammar and Semantics of Sentence Accents, 291-332. Dordrecht: Foris. [Also published in Linguistics 21(1983), 303-339.]

Gussenhoven, Carlos. 2004. The Phonology of Tone and Intonation. Cambridge: Cambridge University Press.

Hayes, Bruce \& Aditi Lahiri. 1991. Bengali intonational phonology. Natural Language \& Linguistic Theory 9, 47-96.

Hellmuth, Sam. 2005. No de-accenting in (or of) phrases: Evidence from Arabic for cross-linguistic and cross-dialectal prosodic variation. In Sónia Frota, Marina Vigario \& Maria J. Freitas (eds.), Prosodies: With Special Reference to Iberian Languages, 99-112. Berlin \& New York: Mouton de Gruyter.

Hellmuth, Sam. 2006. Intonational Pitch Accent Distribution in Egyptian Arabic. Ph.D. dissertation, School of Oriental and African Studies (SOAS), University of London.

Iivonen, Antti. 1998. Intonation in Finnish. In Daniel Hirst \& Albert Di Cristo (eds.), Intonation Systems: A Survey of Twenty Languages, 311-327. Cambridge: Cambridge University Press.

Jóhannsson, Jóhannes L. L. 1924. Nokkrar sögulegar athuganir um helztu hljóðbreztingar o. fl. í islenzku. Reykjavik: Bókaverzlun Sigfúsar Eymundssonar.

Kanerva, Jonni M. 1990. Focusing on phonological phrases in Chicheŵa. In Sharon Inkelas \& Draga Zec (eds.), The Phonology-Syntax Connection, 145-161. Chicago \& London: University of Chicago Press.

Kristoffersen, Gjert. 2000. The Phonology of Norwegian. Oxford: Oxford University Press.

Ladd, D. Robert. 1980. The Structure of Intonational Meaning: Evidence from English. Bloomington, IN \& London: Indiana University Press.

Ladd, D. Robert. 1983. Phonological features of intonational peaks. Language 59(4), 721-759.

Ladd, D. Robert. 1996. Intonational Phonology. Cambridge: Cambridge University Press. Lambrecht, Knud. 1994. Information Structure and Sentence Focus: Topic, Focus, and the Mental Representations of Discourse Referents. Cambridge: Cambridge University Press.

Leben, William. 1973. Suprasegmental Phonology. Ph.D. dissertation, MIT.

McCarthy, John J. 1986. OCP effects: Gemination and antigemination. Linguistic Inquiry 17(2), 207-263.

Nolan, Francis \& Hildur Jónsdóttir. 2001. Accentuation patterns in Icelandic. In Wim A. van Dommelen \& Thorstein Fretheim (eds.), Nordic Prosody: 8th Conference, Trondheim 2000, 187-198. Frankfurt, Berlin \& New York: Peter Lang.

Pierrehumbert, Janet. 1980. The Phonology and Phonetics of English Intonation. Ph.D. dissertation, MIT.

Pierrehumbert, Janet \& Julia Hirschberg. 1990. The meaning of intonational contours in the interpretation of discourse. In Philip R. Cohen, Jerry Morgan \& Martha E. Pollack (eds.), Intentions in Communication, 271-311. Cambridge, MA: MIT Press.

Thráinsson, Höskuldur. 1994. Icelandic. In Ekkehard König \& Johan van der Auwera (eds.), The Germanic Languages, 142-189. London \& New York: Routledge. 